\title{
PHYLOGENETIC RELATIONSHIPS AMONG CHILEAN SPECIES OF DRIMYS (WINTERACEAE) BASED ON ITS SEQUENCES AND INSERTION/DELETION EVENTS
}

\section{RELACIONES FILOGENETICAS ENTRE LAS ESPECIES CHILENAS DE DRIMYS (WINTERACEAE), BASADAS EN SUS SECUENCIAS ITS Y EVENTOS DE INSERCION/DELECION}

\author{
Eduardo Ruiz ${ }^{1}$, Oscar Toro ${ }^{1}$, Daniel J. Crawford², Tod F. Stuessy ${ }^{3}$, María A. Negritto ${ }^{1}$, \\ Carlos Baeza $^{1} \&$ José Becerra $^{1}$
}
${ }^{1}$ Departamento de Botánica, Universidad de Concepción, Casilla 160-C, Concepción, Chile; ${ }^{2}$ Department of Ecology and Evolutionary Biology, Natural History Museum and Biodiversity Research Center, University of Kansas, Lawrence, Kansas, 66045-2106, USA; ${ }^{3}$ Department of Systematic and Evolutionary Botany, University of Vienna, Rennweg 14, A-1030, Vienna, Austria. eruiz@udec.cl

\begin{abstract}
Phylogenetic relationships among Chilean species of Drimys as well as D. granadensis from Central America and D. angustifolia from Brazil were reconstructed using internal transcribed spacers (ITS) of nuclear ribosomal DNA and a parsimony analysis. Our results at the family level were congruent with previous phylogenetic hypotheses. Molecular data indicate that the Juan Fernandez Island endemic $D$. confertifolia diverged early in the evolution of the genus, and it is not closely related to the continental species $D$. winteri, as might be expected on the basis of morphology and biogeography. The ITS phylogeny also provides general support for a recent distribution of species on the western side of the Andes Mountains; the only exception is $D$. andina, which may represent an early divergence that occurred just before the Quaternary. The only species examined from east of the Andes, D. angustifolia, also represents an early divergence in the genus, which is in agreement with the ancient pollen record in Argentinean Patagonia and the lack of Tertiary records in Chile.
\end{abstract}

KEYworDs: Drimys, evolution, ITS, indels, Winteraceae.

\section{RESUMEN}

Se reconstruyeron relaciones filogenéticas de las especies chilenas de Drimys, que incluyó a D. granadensis de América Central y D. angustifolia de Brasil, donde se uso la región del espaciador transcrito interno (ITS) del ADN ribosomal nuclear y sus eventos de inserción/deleción (indels) a través de un análisis de parsimonia. Nuestros resultados a nivel de familia fueron congruentes con previas hipótesis filogenéticas propuestas. Los datos moleculares indican que $D$. confertifolia, endémica del Archipiélago de Juan Fernández, divergió temprano en la evolución del género, y que no está cercanamente emparentada a las especies continentales de $D$. winteri, como se podría esperar sobre la base de la morfología y la biogeografía. Los datos moleculares también apoyan una distribución reciente en el lado oeste de la Cordillera de los Andes, la única excepción es $D$. andina la cual puede representar una divergencia temprana que ocurrió justo antes del Cuaternario. La única especie estudiada del lado este de la Cordillera de los Andes, D. angustifolia, también representa una divergencia temprana en el género, hipótesis que concuerda con el antiguo registro palinológico del Terciario en la Patagonia argentina y la falta de estos en Chile.

Palabras ClaVE: Drimys, evolución, ITS, inserciones, Winteraceae. 
Phylogeny of genus Drimys: RuIz, E. ET AL.

\section{INTRODUCTION}

Drimys J.R.Forst. et G.Forst. (Winteraceae) is distributed exclusively in Central and South America including the Juan Fernández Island and comprises 5 to 7 species (Smith 1943, Ehrendorfer et al. 1979, Vink 1993, Rodríguez \& Quezada 2001). The genus formerly included the species from Australasia as a Sect. Tasmannia (DC.) F.Muell (Vink 1970, 1993). However, recent studies have led to split the genus into two, with New World species remaining in genus Drimys, and the Australasian species classified in genus Tasmannia (Doust \& Drinnan 2004). The relationships among species have been unclear, which has resulted in different perspectives on the limits of species and varieties. At one extreme, Hooker (1845) regarded all central and South American taxa as belonging to a single species. At the other extreme, Miers $(1858,1862)$ recognized nine species in the New World. An intermediate view was proposed by Smith (1943), who recognized four species, three of which possessed infraspecific taxa (i.e., vars.). Ehrendorfer et al. (1979) based on morphological traits, recognized $D$. angustifolia Miers and described a new combination, D. roraimensis (A.C.Smith) Ehrend. et Gliottsb. from Brazil. The taxonomic treatment accorded the Chilean (and adjacent Argentinean) members of Drimys has varied depending on the worker. Currently three species are recognized in Chile (Rodríguez \& Quezada 2001): Drimys andina (Reiche) R.A.Rodr. et Quez., a shrub restricted to higher parts of the Coastal and Andes mountains (37 $43^{\prime}-41^{\circ} 34^{\prime} \mathrm{S}$ ), and two arborescent species, Drimys confertifolia Phil. endemic to the Juan Fernandez Islands and Drimys winteri J.R.Forst. et G.Forst. with two varieties, $D$. winteri var. winteri occurring in Southwestern Patagonia (45 $44^{\prime}$ $55^{\circ} 58^{\prime}$ 'S) and $D$. winteri var. chilensis (DC.) A.Gray being widespread in Chile and Argentina (30²0'$46^{\circ} 25^{\prime} \mathrm{S}$ ) (Fig. 1). The island endemic has been treated as a distinct species (Philippi 1856, Miers 1858, Smith 1943, Rodríguez \& Quezada 2001) or as a variety of D. winteri (Reiche 1895, Johow 1896, Skottsberg 1922). Likewise, $D$. andina has been considered as a variety of $D$. winteri (Philippi 1856, Urban 1934, Smith 1943, Muñoz 1980, Marticorena \& Quezada 1985). Both Ehrendorfer et al. (1979) and Smith (1943) considered both taxa (D. andina and $D$. winteri) to have differentiated due to the uplift of the Andean Mountains. Recently, principally based on morphology, geographical distribution, and ecology,
D. andina has been considered a distinct species (Rodríguez \& Quezada 1991, 2001).

Phenetic analyses of the distribution of flavonoid compounds have shown that $D$. andina has the most distinct array of flavonoid constituents. The flavonoid patterns are congruent with current recognition of $D$. andina and $D$. confertifolia as distinct species (Ruiz et al. 2002).

Several recent phylogenetic studies of Winteraceae have been carried out using DNA sequences. However, these studies are of limited utility for examining patterns of evolution in Drimys, because only one (Suh et al. 1993, Karol et al. 2000) or two (Doust \& Drinnan 2004) species of Drimys were

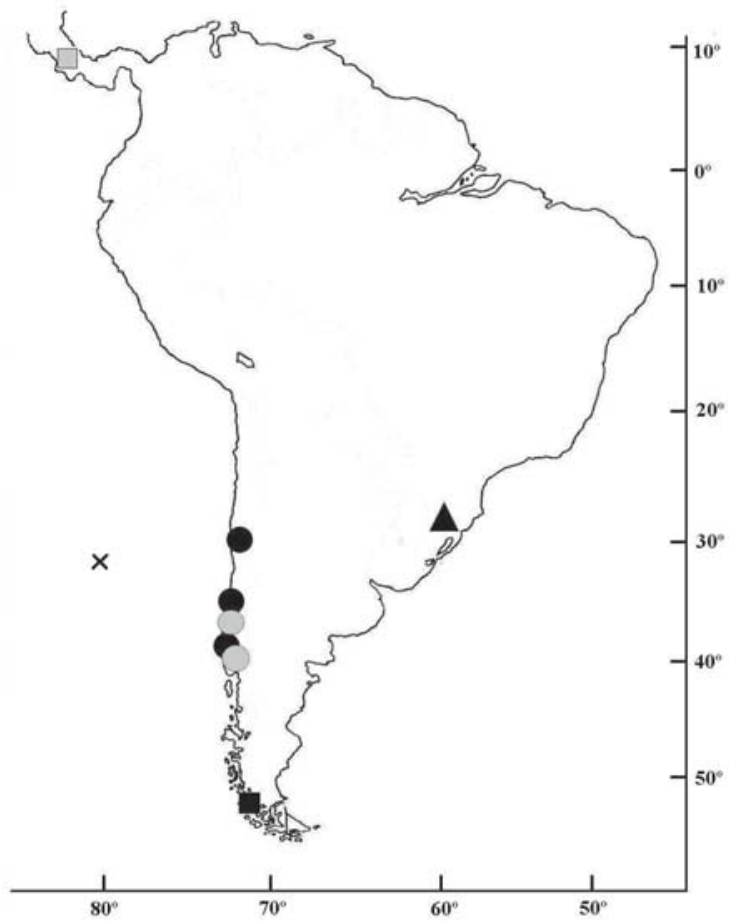

FiguRE 1. Distribution map of species of Drimys used in the current study. The black circles represent $D$. winteri var. chilensis, shaded circles: $D$. andina, black square: $D$. winteri var. winteri, shaded square: $D$. granadensis, black triangle: $D$. angustifolia and cross: $D$. confertifolia.

Figura 1. Mapa de distribución de las especies de Drimys usadas en este trabajo. Los círculos negros representan a $D$. winteri var. chilensis, círculos sombreados: D. andina, cuadrado negro: $D$. winteri var. winteri, cuadrado sombreado: D. granadensis, triángulo negro: $D$. angustifolia, y cruz: D. confertifolia. 
included. Therefore, the purpose of the present study was to produce a hypothesis of phylogenetic relationships in Drimys, and to use the phylogeny as a framework to discuss the biogeography of the genus.

\section{MATERIALAND METHODS}

Plant MATerial

Material of $D$. andina, $D$. confertifolia, $D$. winteri var. chilensis, $D$. winteri var. winteri, was obtained from the field. Material of Drimys angustifolia from Brazil, was kindly sent to us by Dr. Leslie Landum from Arizona State University (ASU). The collected samples were deposited in the herbarium of University of Concepcion (CONC).

Plant Material Studied.

Drimys andina: CHILE. 1. Región de los Lagos, Osorno, upon Volcán Casablanca the limit of the vegetation, Nov. 1997, Ruiz 361 (CONC). 2. Región de la Araucanía, Prov. Malleco, Parque Nacional Nahuelbuta, Piedra del Aguila, 1350 m, Nov. 1985, Rodríguez et al. 2038 (CONC).

Drimys confertifolia CHILE. 1. Región de Valparaíso, Juan Fernández, Más Afuera, up to Cordón Atravesado, in Canelo Bajo, Nov. 1998, Ruiz 783 (CONC). 2. Juan Fernández, Más a Tierra, Salsipuedes ridge 470 m, Jan. 1997, Stuessy et al. 15239 (CONC).

Drimys winteri var. chilensis CHILE. 1. Región de Coquimbo, $5 \mathrm{~km}$ North from Los Vilos, small wet forest in the coastal side of the highway, Sept. 1997, Ruiz 301 (CONC). 2. Región de Bío-Bío, between Concepción and Santa Juana, Patagual bridge, trail to Coronel, two km toward Coronel, Oct 1997, Ruiz 330 (CONC). 3. Región de la Araucanía, Pto. Saavedra, from Pelarco, $2 \mathrm{~km}$ to the South, Nov 1997, Ruiz 389(CONC).

Drimys winteri var. winteri. CHILE. Región de Magallanes. Provincia de Magallanes. Punta Arenas, Sector Faro San Francisco, en bosque costero de Nothofagus, 4 m, Feb 2006, Baeza 40a (CONC).

Drimys angustifolia. BRAZIL. RS- Mum. Bom JesusFazenda Carúno, 1200 m, Jan 1997, R. Wasum \& R.C. Molon s/n (ASU).
DNA EXTRACTION, AMPLIFICATION AND SEQUENCING Total DNA was extracted from young leaf tissue using the CTAB method of Doyle \& Doyle (1987). Doublestranded DNA of the complete region (ITS-1, 5.8S and ITS-2) was amplified by a symmetric PCR using White's universal ITS primers (1990): ITS 2 and 5, and ITS 3 with ITS 4 when necessary. The PCR products were obtained using the following reaction conditions: The $25 \mu \mathrm{L}$ PCR reaction contained $17.125 \mu \mathrm{L}$ sterile water, $2.5 \mu \mathrm{L} 10 \mathrm{X}$ Taq polymerase reaction buffer, $50 \mathrm{mM}$ magnesium chloride, $1 \mu \mathrm{l}$ of each primer (0.4 $\mu \mathrm{M}), 0.125$ units Taq polymerase and 2-10 ng template total DNA. In addition, $1 \mu \mathrm{L}$ DMSO was added to both the labelling and termination reactions to reduce the effects of secondary structure (Cosner et al. 1994). The first cycle consisted of $4 \mathrm{~min} 30 \mathrm{sec}$ at $95^{\circ} \mathrm{C}$ to denature template DNA, 1 min at $45^{\circ} \mathrm{C}$ to anneal primers and $1 \mathrm{~min}$ at $72{ }^{\circ} \mathrm{C}$ to extend primers. Denaturating time was reduced to $1 \mathrm{~min}$ and the annealing temperature increased to $48^{\circ} \mathrm{C}$ for each of the next 34 cycles. A final extension period of $9 \mathrm{~min}$ at $72{ }^{\circ} \mathrm{C}$, terminated the PCR reaction. The amplification products were purified using QIAquick PCR Purification Kit (Quiagen) following the protocols suggested by manufacturers.

All the samples, except for $D$. angustifolia and $D$. winteri var. winteri, were directly sequenced by a cycle-sequencing ABI 377 automated sequencer (Applied Byosistem, Inc.), following the manufactures protocols. The $D$. angustifolia and $D$. winteri var. winteri ITS samples were sequenced in CESAT (Centro de Equipamiento y Servicio Tecnológico) at the University of Chile. All Drimys sequences were aligned with Clustal X (Thompson et al. 1997) with manual adjustment of the alignment by eye, and compared with the general matrix of Winteraceae and Canellaceae published by Karol et al. (2000) available in the web on TreeBASE (www.treebase.org/treebase). The current Drimys sequences are also available in Genbank (Table I).

\section{DATA MATRIX}

The ITS sequences of $D$. granadensis, Tasmannia xerophila (P.Parm) Gray, Tasmannia stipitata (Vickery) A.C.Smith, Tasmannia glaucifolia J.B.Williams and Tasmannia purpurescens (Vickery) A.C.Smith were obtained from GenBank (Table I). The indel data were coded as presence/absence $(0=$ absent, 1 = present) following Simmons \& Ocheterena (2000) and added to the matrix for maximum parsimony (MP) analysis. These results were subsequently 
Phylogeny of genus Drimys: RuIz, E. ET AL.

TABLE I. List of taxa used and Genbank accession numbers.

TABLA I. Lista de taxa utilizados y sus números de acceso a Genbank.

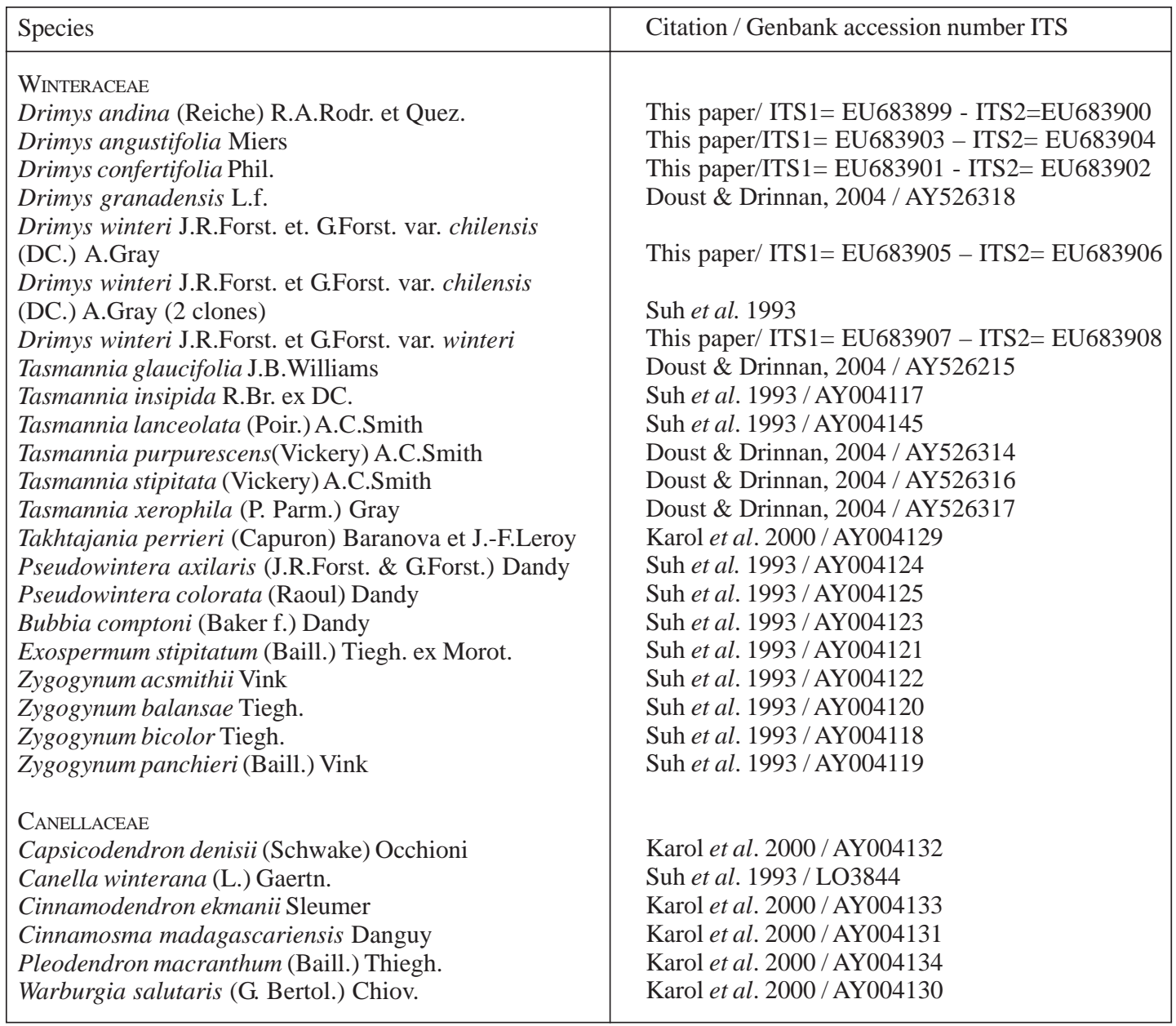

compared to previous results where indels were only mapped onto the phylogeny (Suh et al. 1993, Karol et al. 2000, Doust \& Drinnan 2004). To estimate phylogeny within Drimys, a new matrix including five species of Drimys (including the two varieties of $D$. winteri) and two species of Pseudowintera Dandy as outgroup was constructed and analyzed using MP.

\section{AnALyses}

MP analyses were conducted using PAUP* 4.0 (Swofford 2000). The analysis were conducted for both matrices using a heuristic search option with 2000 interations, retaining 5 trees for each replicate, and using the RAS + TBR + MULTREES option to save all possible minimum length trees. All characters (base pair positions and indels) were considered as unordered and equally weighted (Fitch 1971). Relative support for the clades recovered was assessed via bootstrap analysis (Felsenstein 1985, Hills \& Bull 1993) using 1000 replicates and 10 random addition sequences and TBR branch swapping.

\section{RESULTS}

The complete ITS sequences (without 5.8S) were 475 bp for $D$. andina, D. confertifolia and $D$. angustifolia, and 476 bp for each variety of $D$. winteri. Intraspecific variation was not found. Although all sequences are very similar among the species, the ITS1 region was more variable in length 
Gayana Bot. 65(2), 2008

than ITS2, ranging from 249 bp in D. andina to 252 bp in $D$. winteri. In the present work no variation was found among the varieties of $D$. winteri. However, we found few differences with those obtained by Suh et al. (1993). To align Drimys and Pseudowintera sequences, it was necessary to infer 18 indels. Nearly 53\% of the variable sites among Drimys species are represented by indels. The complete data matrix (including Canellaceae and other Winteraceae taxa) had 739 characters, 112 were indels, and 278 characters were parsimony informative. The Drimys and Pseudowintera matrix had 486 characters, 35 were parsimony informative, and 13 indels. Using the complete data matrix, parsimony analysis recovered six MP trees of 624 steps with a $\mathrm{CI}=0.8221$ and $\mathrm{RI}=0.9$ (477 steps, $\mathrm{CI}=$ 0.738 and $\mathrm{RI}=0.9$ with informative characters only). The cladogram (Fig. 2) shows all species of Drimys as a monophyletic group supported by a bootstrap value of $100 \%$. In spite of an unresolved Drimys

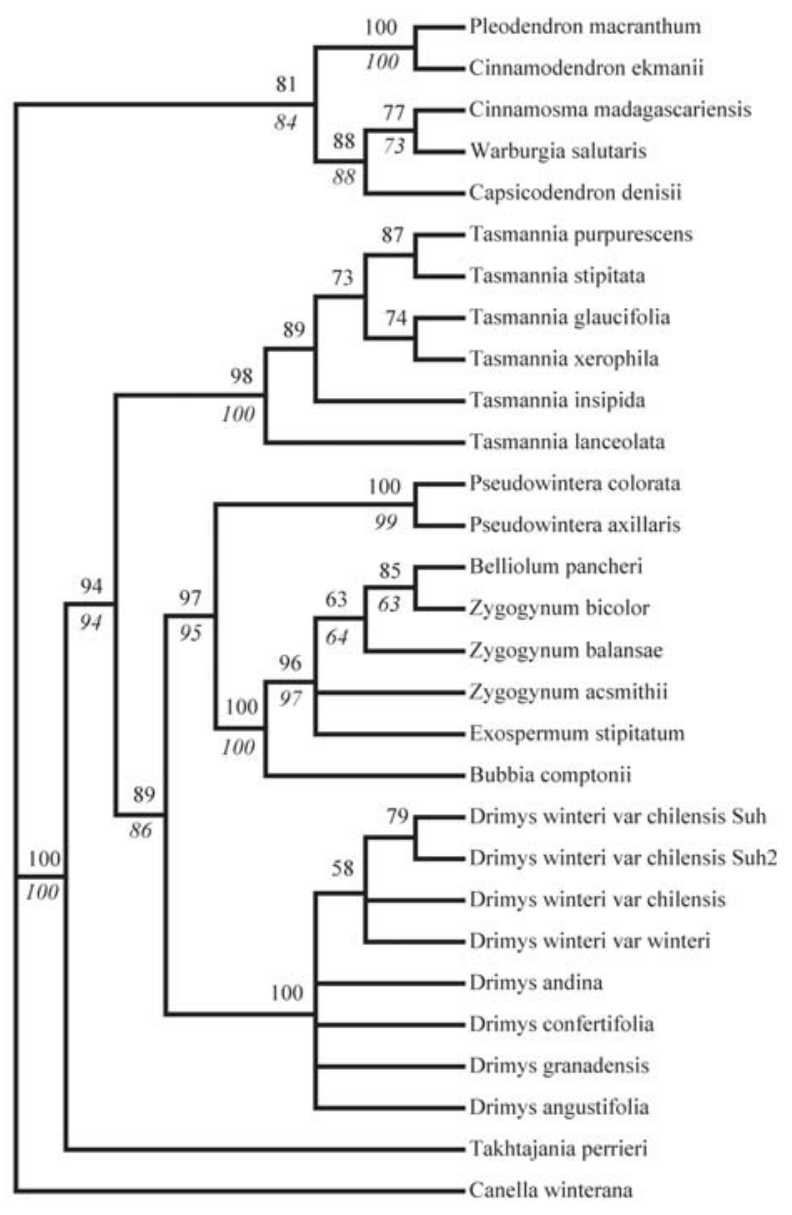

FIGURE 2. Strict consensus of 6 most parsimonious trees and generated from a combined ITS + indel matrix. Tree length $=624$ steps (477 steps excluding uninformative characters), $\mathrm{CI}=0.798$ ( 0.738 excluding uninformative characters) and $\mathrm{RI}=0.899$ (0.899 excluding uninformative characters). Bootstrap support values greater than $50 \%$ are indicated above and below; values above the branches are estimated from our analyses whereas those below the branches are from Karol et al. (2000).

FIgURA 2. Consenso estricto obtenido de los 6 árboles más parsimoniosos y generado con los datos combinados del ITS y los indels. El largo del árbol $=624$ pasos (477 excluyendo a los caracteres no informativos), CI $=0,798(0,738$ excluyendo a los caracteres no informativos) y un RI $=0,899$ (0,899 excluyendo a los caracteres no informativos). Los números sobre y bajo las ramas corresponden a los índices de bootstrap calculados en este trabajo y los publicados por Karol et al. (2000), respectivamente. 
branch, relationships among the remainder of Winteraceae are well resolved and consistent with those obtained by Suh et al. (1993), Karol et al. (2000) and Doust \& Drinnan (2004).

The MP analysis of Drimys, considering Pseudowintera species as outgroup, recovered two most parsimonious trees of 67 steps with $\mathrm{CI}=0.985$, RI $=0.98$ (48 steps, $\mathrm{CI}=0.975, \mathrm{RI}=0.980$, excluding uninformative characters, Fig. 3). Only bootstrap values higher than 50\% are shown above each branch. The only discrepancy between these trees involves the relationship among $D$. andina and $D$. confertifolia with the remaining species of Drimys. In Figure 3A, 54\% of the characters supporting the branches are indels and in Figure 3B 60\% of the characters are indels. Both cladograms show $D$. andina as the most divergent species. Although with low bootstrap support, $D$. winteri is represented as a monophyletic group.

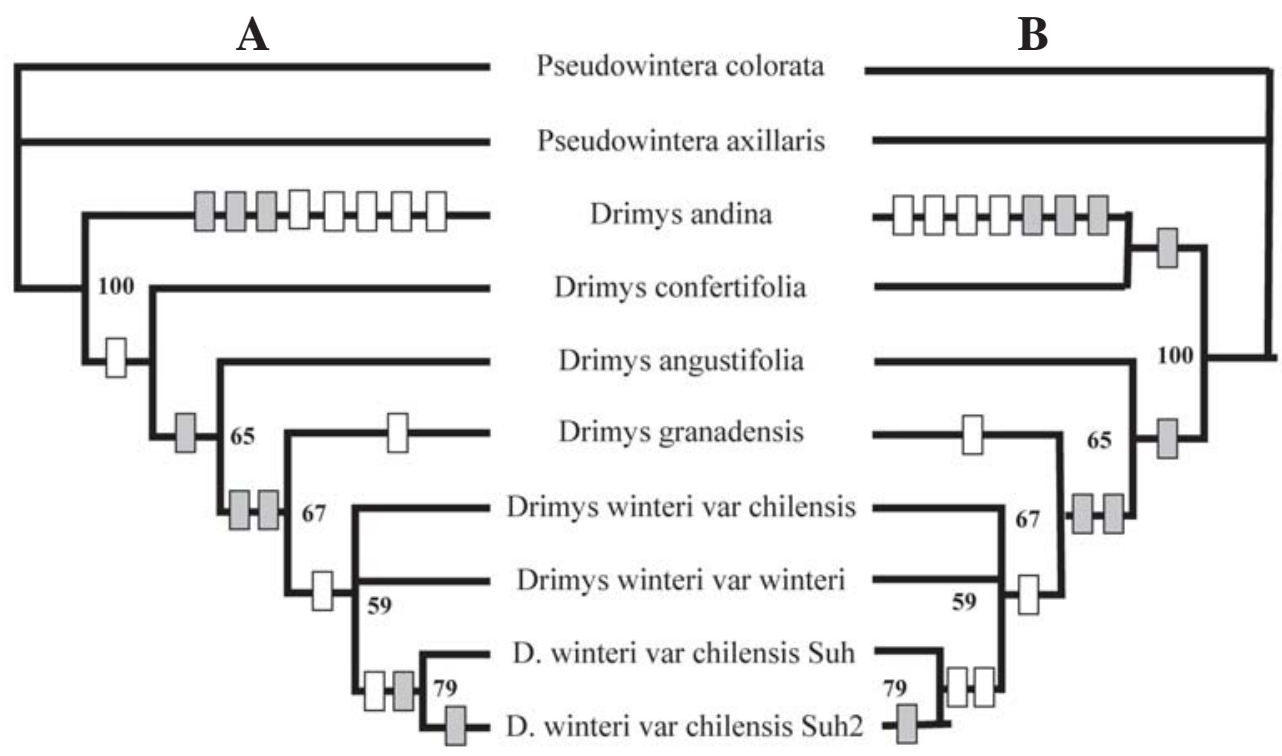

FIGURE 3. The two most parsimonious trees (A and B) obtained from ITS data plus indels. Tree length $=67$ steps with $\mathrm{CI}=0.985$, RI $=0.98$ (48 steps, $\mathrm{CI}=0.975, \mathrm{RI}=0.980$, excluding uninformative characters), with bootstrap values obtained from $50 \%$ majority rule tree. Bootstrap support values greater than $50 \%$ are indicated. Shaded squares represent indels whereas plain squares show molecular characters mapped on both trees.

Figura 3. Los dos árboles más parsimoniosos (A y B) obtenidos a partir del ITS más indels. Largo del árbol =67 pasos con $\mathrm{CI}=0,985, \mathrm{RI}=0,98$ (48 pasos, $\mathrm{CI}=0,975, \mathrm{RI}=0,980$, excluyendo los caracteres no informativos). Los valores de soporte inferiores al 50\% no fueron mostrados. Los cuadrados sombreados representan a las inserciones, mientras que cuadrados blancos muestran los caracteres moleculares mapeados en ambos árboles.

\section{DISCUSSION}

The present work is the first attempt to study the relationships among species of Drimys from a molecular perspective. Previous studies have considered only one or two species in the context of a broad family-level phylogenetic analysis (Suh et al. 1993, Karol et al. 2000, Doust \& Drinnan 2004). In this study we incorporated five species of Drimys as well as two varieties of $D$. winteri (var. winteri and var. chilensis). As would be expected, the parsimony analysis of Winteraceae resulted in higher bootstrap support for clades when indels were included in the analysis. The phylogenetic hypothesis of Winteraceae obtained by Suh et al. (1993), Karol et al. (2000) and Doust \& Drinnan (2004) were very similar, indicating that Pseudowintera is the most closely related genus to the common ancestor with Drimys. Although there were differences between our $D$. winteri sequences and 
those of Suh et al. (1993), the varieties of this species form a monophyletic group.

ITS sequences of Drimys species are very similar, except for $D$. andina. Except for the latter species, this result is consistent with the high uniformity of morphological characters among the taxa (Smith 1943). Drimys confertifolia was expected to be closely allied to $D$. winteri based on the general biogeographic pattern that most species endemic to the Juan Fernandez Islands have their closest relatives in continental Chile (Skottsberg 1956, Stuessy et al. 1990, 2005, Ruiz et al. 2004). The relationships portrayed in the molecular phylogeny are somewhat unexpected because of the morphological similarity between $D$. confertifolia and $D$. winteri, and the aforementioned biogeographic relationships between continental Chile and the Juan Fernandez Islands. The early divergence of the island species in the phylogeny is also somewhat surprising and differs from other Juan Fernandez endemics such as the genera Dendroseris (Kim et al. 2007) and Robinsonia (Pelser et al. 2007), both of which are nested within otherwise continental genera. Since $D$. confertifolia diverged from a common ancestor of continental tree species within the last 4 millions year, the estimated age for Robinson Crusoe Island (Stuessy et al. 1984), this means that divergence among the majority of other contemporary species in Drimys occurred within the last four million years. It should be noted that our results showing an early divergence for $D$. confertifolia are concordant with the view of Smith (1943), who indicated that D. confertifolia is an ancestral species, based on its high number of ovules, a character that was considered by that author as primitive within the group.

Smith (1943) and Ehrendorfer et al. (1979) indicated that $D$. andina and $D$. winteri var. winteri may have originated from $D$. winteri var. chilensis where by both the Andes Mountain elevation and Pleistocene changes might have been important factors in the evolution of the continental Chilean species of Drimys. Palynologic records indicate "winteroid" pollen in Late Eocene from Argentinean Patagonia (Barreda 1997, Doyle 2000), although, in Chile the pollen record of Drimys dates only from the Quaternary (Heusser 1981, Heusser et al. 1999, Villagrán 2001) when the maximum elevation of Andean Mountains already existed (Solbrig et al. 1977). Thus, it is presumed that the species of Drimys distributed on the western side of the Andes would be of more recent origin. Our results support this hypothesis because of the low ITS sequence divergence among western species.

What is problematical, however, is the high sequence divergence of $D$. andina, a species occurring west of the Andes (Fig. 1). A plausible explanation could be that $D$. andina, a shrubby species, was the first that diverged before the Quaternary, restricted to the high parts of the Andes, which reached their current elevation during the Pliocene (Solbrig 1976).

Ehrendorfer et al. (1979) stated that the Brazilian group (D. angustifolia, D. brasiliensis and $D$. roraimensis) was ancestral within the genus based on their analysis of morphological traits. Although, we were able to sequence only one species from Brazil, our results and the palynologic records agree with this hypothesis, indicating that $D$. angustifolia is the basalmost arborescent continental species. It would be highly desirable to have sequences of the other species from Brazil, D. brasiliensis and $D$. roraimensis, to test this hypothesis.

\section{ACKNOWLEDGMENTS}

The authors thank Dr. Leslie Landrum, for kindly sending us D. angustifolia samples, Dra. Sylvia Palma Heldt for help with palynologic information, Fundación Andes C-14055 and Dirección de Investigación, Universidad de Concepción for financial support, and CONAF Juan Fernandez, for logistical help.

\section{REFERENCES}

Barreda, V. 1997. Palynomorph assemblage of the Chenque formation, late Oligocene?-Miocene from golfo San Jorge basin, Patagonia, Argentina, Part 4: Polycolporate and Porate pollen. Ameghiniana 34: 145-154.

Cosner, M.B., R.K. Jansen \& T.G. Lammers. 1994. Phylogenetic relationships in the Campanulales based on $r b c L$ sequences. Plant Systematic and Evolution 190: 79-95.

Doust, A.N. \& A.N. Drinnan. 2004. Floral development and Molecular Phylogeny support the Generic Status of Tasmannia (Winteraceae). American Journal of Botany 91: 321-331.

Doyle, J.A. 2000. Paleobotany, Relationships, and Geographical History of Winteraceae. Annals of Missouri Botanical Garden 87: 303-317.

Doyle, J.J. \& J.L. Doyle. 1987. A rapid DNA isolation procedure for small quantities of fresh leaf tissue. Phytochemical Bulletin 19: 11-15. 
Phylogeny of genus Drimys: RuIz, E. ET AL.

Ehrendorfer, F., I. Silberbauer-Gottsberger \& G. GotTsberger. 1979. Variation on the Population, Racial, and Species level in the Primitive Relict Angiosperm Genus Drimys (Winteraceae) in South America. Plant Systematics and Evolution 132: 53-83.

Felsenstein, J. 1985. Confidence limits on phylogenies: an approach using the bootstrap. Evolution 39: 783-791.

Fitch, W.M. 1971. Toward defining the course of evolution: Minimum change for a specific tree topology. Systematic Zoology 20: 406-466.

Heusser, C.J. 1981. Palynology of the Last InterglacialGlacial Cycle in Midlatitudes of Southern of Chile. Quaternary Research 16: 293-321.

Heusser, C.J., L.E. Heusser \& T.V. Lowell. 1999. Paleoecology of the southern Chilean lake districtIsla Grande de Chiloé during Middle-Late Llanquihue glaciation and deglaciation. In: Geofisika Annaler, Series A, Physical Geography, vol. 21, pp. 231-284. Published by Swedish Society for Antropology and Geography.

Hills, D.M. \& J.J. Bull. 1993. An Empirical Test of Boostraping as a Method for Assessing Confidence in Phylogenetic Analysis. Systematic Biology 42: 182-192.

Hooker, J.D. 1845. The botany. The antarctic voyage of H.M. discovery ships Erebus and Terror in the years 1839-1843. Under the command of Captain Sir James Clark Ross. London I. Flora antarctica. xii, 574 pp., 198 lám.

JoHow, F. 1896. Estudio sobre la flora de las Islas de Juan Fernández. Santiago. xi, 287 pp., errata, 18 lám., 2 mapas.

Karol, K.G., Y. Suh, G.E. Schatz \& E.A. Zimmer. 2000. Molecular evidence for the position of Takthajania in the Winteraceae: inference from nuclear ribosomal and chloroplast gene spacer sequences. Annals of the Missouri Botanical Garden 87: 414-432.

KIM, S.-C., L. ChungheE \& J.A. MeJias. 2007. Phylogenetic analysis of chloroplast matK gene and ITS of nrDNA sequences reveals polyphyly of the genus Sonchus and new relationships among the subtribe Sonchinae (Asteraceae: Cichorieae). Molecular Phylogenetics and Evolution 44: 578-597.

Marticorena, C. \& M. Quezada.1985. Catálogo de la Flora Vascular de Chile. Gayana Botánica 42: 1-155.

Miers, J. 1858. On the Winteraceae. Annals and Magazine of Natural History 2: 33-48, 109-115.

Miers, J. 1862. On the Winteraceae. Contributions to botany, iconographic and descriptive, detailing the charactes of plants that are either new or imperfectly described; to which are added remarks on their affinities,1:123-145, tab. 25-27.

MuÑoz, M. 1980. Flora del parque nacional Puyehue. Editorial Universitaria. Santiago. Chile. 557 pp.

Pelser, P. B., B. Nordenstam, J. W. Kadereit \& L. E. Watson. 2007. An ITS phylogeny of tribe Senecioneae (Asteraceae) and a new delimitation of Senecio L. Taxon 1077-1104.
PhiLlipPI, R.A. 1856. Observaciones sobre la flora de Juan Fernández. Anales de la Universidad de Chile 13:157-169.

Reiche, C. 1895. Drimys Forst. Anales de la Universidad de Chile 88:55-100.

RodríGuez, R. \& M. QuEZADA. 1991. Nueva Combinación en Drimys J.R. et G.Forster (Winteraceae) de Chile. Gayana Botánica 48: 111-114.

Rodríguez, R. \& M. Quezada. 2001. Winteraceae. En: C. Marticorena \& R. Rodríguez (eds.), Flora de Chile 2(2): 2-6.

Ruiz, E., G. Fuentes, J. Becerra, F. GonzÁlez \& M. Silva. 2002. Flavonoids as Chemosystematic marker of Drimys J.R. Forst. et G. Forst. (Winteraceae). Boletín de la Sociedad Chilena de Química 3: 273-278.

Ruiz, E., D.J. Crawford, T.F. Stuessy, F. González, R. Samuel, J. Becerra \& M. Silva. 2004. Phylogenetic relationships and genetic divergence among endemic species of Berberis, Gunnera, Myrceugenia and Sophora of the Juan Fernandez Islands (Chile) and their continental progenitors based on isoenzymes and nrDNA sequences. Taxon 53(2): 321-332.

Simmons, M.P. \& H. OCHETERENA. 2000. Indels as character in sequence-based phylogenetic analyses. Systematic Biology 49: 369-381.

SкотtSBERG, C. 1922. The phanerogams of Juan Fernandez Islands. Natural History of Juan Fernandez and Easter Islands 2: 95-240.

SkotTSBerg, C. 1956. Derivation of the flora and fauna of Juan Fernandez and Easter Islands. Natural History of Juan Fernandez and Easter Islands 1: 193-405.

SмIтH, A.C. 1943. The American species of Drimys. Journal of the Arnold Arboretum 24:1-33.

Solbrig, O. 1976. The origin and floristic affinities of the South American temperate desert and semidesert regions. In: D.W. Goodall (ed.), Evolution of desert biota. University Texas Press. Texas. 7-49.

Solbrig, O., M.L. Cody, E.R. Fuentes, W. Glanz, J.H. Hunt \& A.R. Moldenke. 1977. The origin of the biota. In: Convergent evolution in Chile and California: Mediterranean climate ecosystems (Ed. H.A. Mooney). Dowden. Hutchinson and Ross Stroudsburg. 13-26.

Stuessy, T. F., K.A. Foland, J.F. Sutter, R.W. Sanders \& M. Silva. 1984. Botanical and geological significance of potassium-argon dates from the Juan Fernandez Islands. Science 225: 49-51.

Stuessy, T. F., D.J. Crawford \& C. Marticorena. 1990 Patterns of phylogeny in the vascular flora of the Juan Fernandez Islands, Chile. Systematic Botany 225: 49-51.

Stuessy, T.F., E. Ruiz, D.J. Crawford \& K. TREMETSBerger. 2005. Testing degrees of genetic divergence and populational variation in oceanic island archipielagos: Juan Fernandez as a model system. Nova Acta Leopoldina 342: 147-165.

Suh Y., L.B. Thien, H.E. Reeve \& E.A. Zimmer. 1993. Molecular evolution and phylogenetic implications of internal transcribed spacer sequences of 
Gayana Bot. 65(2), 2008

ribosomal DNA in Winteraceae. American Journal of Botany 80: 1042-1055.

Swofford, D. L. 2000. PAUP*. Phylogenetic Analysis Using Parsimony (*and Other Methods). Version 4.0b10 Sinauer Associates, Sunderland, Massachusetts.

Thompson, J.D., T.J. Gibson, F. Plewniak, F. Jeanmougin \& D.G. Higgins. 1997 The Clustal X windows interface: flexible strategies for multiple sequences alignment aided by quality analysis tools. Nucleic Acids Research 24: 4876-4882.

UrBAn, O. 1934. Botánica de plantas endémicas de Chile. Concepción. 292 pp.

Villagrán, C. 2001. Un modelo de la historia de la vegetación de la Cordillera de la Costa de Chile central-sur: la hipótesis glacial de Darwin. Revista Chilena de Historia Natural 74: 793-803.

VInK, W. 1970. The Winteraceae the Old World. I. Pseudowintera and Drimys-Morphology and taxonomy. Blumea 18: 225-354.

VINK, W. 1993. Winteraceae. In: K. Kubitzki, J. G. Rohwer \& V. Bittrich (eds.), The Families and Genera of Vascular Plants, Vol. 2. Springer-Verlag. Berlin. 630-638.

White, T.J., T. Burns, S. Lee \& J. Taylor. 1990. Amplification and direct sequencing of fungal ribosomal RNA genes for phylogenetics. In: PCR Protocols: A guide to Methods and Applications. Academic Press.

Recibo: 18.10 .07

Aceptado: 15.05 .08 